\title{
PROFIL KEMAMPUAN MATEMATIKA SISWA SMP DI KOTA CIREBON BERDASARKAN STANDAR TIMSS
}

\author{
Munaji1', Mochamad Iman Setiawahyu² \\ 1,2 Universitas 17 Agustus 1945 Cirebon, Jl. Perjuangan No.17 Cirebon, Indonesia \\ Email: munaj@untagcirebon.ac.id
}

\begin{abstract}
Indonesian students' scores in the Trend International in Mathematics and Science Study (TIMSS) are at the bottom. However, there have been no results of research on the position where students in Cirebon are currently in TIMSS scores. This research aims to describe the mathematical abilities profile of junior high school students in Cirebon based on TIMSS standards. The method used in this study is the cross-sectional survey model method. Sampling technique using simple random sampling technique, with subjects of grade VIII junior high school as many as 676 students from state and private schools. The collection of mathematical ability data is done by providing TIMSS model mathematics tests that have been translated into Indonesian. The results of this study showed that the average math score of junior high school students in Cirebon reached 498, better when compared to the average national TIMSS score of 386 . But it is slightly lower than the international TIMSS score of 500. Based on gender differences, female students in Cirebon are better than male students both reviewed from the level of mathematical ability and reviewed from the TIMSS domain. The mathematics abilities of junior high school students in Cirebon still need to be improved, especially in the domain of applying and reasoning.
\end{abstract}

Keywords: Cognitive domian, content domain, mathematical ability, TIMSS

\begin{abstract}
ABSTRAK
Skor siswa Indonesia dalam Trend International in Mathematics and Science Study (TIMSS) berada pada posisi bawah. Namun demikian belum ada hasil penelitian pada posisi mana siswa di kota Cirebon saat ini dalam skor TIMSS. Penelitian ini bertujuan untuk mendeskripsikan profil kemampuan matematika siswa SMP di kota Cirebon berdasarkan standar TIMSS. Metode yang digunakan dalam penelitian ini adalah metode survei model cross-sectional survey. Teknik pengambilan sampel menggunakan teknik simple random sampling, dengan subyeknya siswa kelas VIII SMP sebanyak 676 siswa dari sekolah negeri dan swasta. Pengumpulan data kemampuan matematika dilakukan dengan memberikan tes matematika model TIMSS yang telah diterjemahkan ke dalam bahasa Indonesia. Hasil penelitian ini menunjukkan bahwa rata-rata skor kemampuan matematika siswa SMP di kota Cirebon mencapai 498, lebih baik bila dibandingkan dengan rata-rata skor TIMSS secara nasional yang mencapai 386. Namun sedikit lebih rendah dari skor TIMSS internasional yang mencapai skor 500. Berdasarkan perbedaan gender, siswa perempuan di kota Cirebon lebih baik dibandingkan siswa laiki-laki baik ditinjau dari level kemampuan matematika maupun ditinjau dari domain TIMSS. Kemampuan matematika siswa SMP di kota Cirebon masih perlu ditingkatkan lagi terutama pada domain applying dan reasoning.
\end{abstract}

Kata kunci: Domain kognitif, domain konten, kemampuan matematika, TIMSS

Dikirim: 29 Juli 2020; Diterima: 26 Agustus 2020; Dipublikasikan: 30 September 2020

Cara sitasi: Munaji \& Setiawahyu, M. I. (2020). Profil kemampuan matematika siswa smp di kota cirebon berdasarkan standar timss. Teorema: Teori dan Riset Matematika, 5(2), 249-262. 


\section{PENDAHULUAN}

Matematika adalah sarana untuk berpikir ilmiah, deduktif, formal dan abstrak (Shintawati \& Jupri, 2018). Matematika ada di sekeliling kita baik yang terlihat secara nyata seperti bentuk-bentuk bangunan yang merupakan bentuk geometri dimensi dua ataupun dimensi tiga dan penggunaan konsep aritmetika ketika seseorang berbelanja di supermarket yang memberikan diskon, maupun secara samar, seperti susunan nomor handphone yang disusun dengan susunan yang berbedaberbeda dan tidak ada satupun nomor handphone yang sama karena menggunakan konsep permutasi. Hal ini sejalan dengan apa yang katakan oleh Yunia \& Zanthy (2020) bahwa matematika adalah ilmu hitung yang sangat berguna untuk diaplikasikan di lingkungan sekolah maupun lingkungan masyarakat sekitar, karena berbagai aspek kehidupan yang kita jalani saat ini banyak interaksi yang menggunakan konsep matematika. Oleh karena itu, pembelajaran matematika tidak dapat dipisahkan dari konteks kehidupan sehari-hari karena sejatinya matematika adalah manifestasi ide-ide dari dunia nyata.

Matematika merupakan bahasa simbol yang tanpa makna jika matematika itu sendiri tidak berperan dalam menyelesaikan masalah dalam aktivitas manusia. Dengan demikian, sejalan dengan pendapat Musyafa et al., (2020) matematika lebih luas dari sekedar rumus-rumus yang kaya akan simbol-simbol dan perhitungan yang rumit dan kebanyakan siswa menganggapnya mata pelajaran yang sulit. Oleh karena itu dalam kajian Trend International Mathematics and Science Study (TIMSS) prestasi matematika siswa diukur dari kemampuannya dalam menyelesaikan soal-soal berupa pengetahuan siswa mengenai konsep-konsep matematika, mengaplikasikan konsep-konsep matematika untuk menyelesaikan masalah seharai-hari, dan melakukan penalaran, memberikan alasan berdasarkan informasi, menarik kesimpulan dan membuat generalisasi. Hasil pengukuran kemampuan matematika TIMSS tersebut dijadikan sebagai evaluasi dan pemeringkatan mutu pendidikan. Mengetahui posisi peringkat mutu pendidikan suatu daerah sangatlah penting untuk mengetahui potensi yang dimiliki dan bagian-bagian yang perlu diperbaiki dan ditingkatkan.

Mutu pendidikan dapat dilihat dari hasil evaluasi yang dilakukan di tingkat lokal, daerah, nasional maupun internasional. Salah satu lembaga internasional yang melakukan evaluasi terhadap prestasi siswa dalam bidang matematika adalah International Association for the Evaluation of Education Achievment (IEA) melalui study TIMSS dengan melakukan survei kepada siswa kelas IV SD dan kelas VIII SMP. Survei ini dilakukan setiap empat tahun sekali. Survei dilakukan pertama kali tahun 1999 dan terakhir kali pada tahun 2019. Untuk survei TIMSS 2019 ini, sampai dengan dilakukannya penelitian oleh penulis, hasilnya belum pernah dipublikasikan. Sedangkan pada tahun 2015 siswa SMP Indonesia tidak ikut serta dalam survei ini. Berdasarkan hasil survei TIMSS pada tahun 2011, Indonesia menempati posisi ke 38 dari 42 negara dengan skor rata-rata sebesar 386 di bawah rata-rata skor TIMSS yang berkisar di skor 500. Posisi ini jauh tertinggal dengan negaranegara tetangga seperti Malaysia yang berada di posisi ke 26 dan Singapura di posisi ke 2. Bahkan skor TIMSS siswa Indonesia di bawah Palestina yang sedang dilanda perang berada di posisi ke 36, (Setiadi et al., 2012). Posisi ketertinggalan siswa Indonesia juga terlihat dalam skor PISA 2018 yang menempatkan Indonesia pada ranking ke 72 dari 78 negara (OECD, 2019). Rendahnya prestasi matematika siswa Indonesia ini disebabkan oleh beberapa faktor. Diantara penyebabnya antara lain karena peserta didik di Indonesia kurang terbiasa dalam menyelesaikan soal-soal kontekstual, membutuhkan penalaran, argumentasi dan kreativitas dalam meyelesaikannya (Setiadi et al., 2012), dimana soal-soal tersebut merupakan karakteristik soal-soal TIMSS. (Wardhani \& Rumiati, 2011) mengatakan bahwa salah satu faktor penyebab rendahnya peringkat siswa Indonesia dalam TIMSS dan PISA adalah siswa Indonesia pada umumnya kurang terlatih dalam menyelesaikan soal-soal dengan karakteristik seperti soal-soal pada TIMSS dan PISA.

Penelitian yang bertujuan mendeskripsikan profil kemampuan matematika dengan subyek penelitianya siswa SMP pernah dilakukan oleh Ani \& Rahayu (2018) yang mengelompokkan kemampuan pemecahan masalah matematika ke dalam kemampuan tinggi, sedang, dan rendah. Hasil penelitiannya menunjukkan bahwa subyek berkemampuan tinggi dalam memecahkan masalah 
termasuk kategori baik, subyek berkemampuan sedang dalam memecahkan masalah termasuk dalam kategori cukup, dan subyek berkemampuan rendah dalam memecahkan masalah termasuk dalam kategori kurang. Sementara itu, Nur \& Palobo (2018) mendeskrpisikan profil kemampuan pemecahan masalah matematika siswa ditinjau dari perbedaan gaya kognitif dan gender. Hasil penelitiannya menunjukkan subyek: (1) file dependent (FD) laki-laki mampu memecahkan masalah pada kategori cukup; (2) subjek FD perempuan mampu memecahkan masalah pada kategori kurang; (3) subjek file independent (FI) laki-laki mampu memecahkan masalah pada kategori baik; dan (4) subjek FI perempuan mampu memecahkan masalah pada kategori baik. Utami et al. (2020) dalam penelitiannya mendeskripsikan profil kemampuan berpikir aljabar dalam memecahkan masalah matematika ditinjau dari gaya kognitif reflektif. Hasil penelitiannya menunjukkan bahwa profil kemampuan berpikir aljabar dalam memecahkan masalah matematika subjek dengan gaya kognitif reflektif memenuhi 5 indikator, yaitu, generalisasi, abstraksi pemodelan, berpikir analitik, dan berpikir dinamik. Kesamaan penelitian ini dengan penelitian yang telah dilakukan Ani \& Rahayu (2018); Nur \& Palobo (2018); dan Utami et al. (2020) adalah subyeknya sama-sama siswa SMP dan tujuan penelitiannya yaitu mendeskripsiskan profil kemampuan terkait matematika. Namun, yang membedakannya adalah kemampuan matematika yang diukur dalam penelitian ini adalah kemampuan matematika standar TIMSS. Sepanjang penelusuran peneliti, belum ada penelitian yang dilakukan untuk mengetahui prestasi matematika siswa SMP di kota Cirebon berada di posisi mana bila dibandingkan dengan skor TIMSS. Oleh karena itu tujuan dari penelitian ini adalah mendeskripsikan profil kemampuan matematika siswa SMP di kota Cirebon berdasarkan standar TIMSS dengan mendeskripsikan kemampuan matematika berdasarkan: (1) level kemampuan rendah, menengah, tinggi dan mahir; (2) domain konten dan kognitif; dan (3) perbedaan gender.

Kemahiran atau kemampuan matematika dibutuhkan dalam setiap aktivitas sehari-hari karena kemampuan matematika merupakan bagian dari kecakapan hidup (life skill) terutama dalam pengembangan penalaran, komunikasi, dan pemecahan masalah (As'ari et al., 2017). Kemampuan pemecahan masalah merupakan tujuan utama dalam pembelajaran matematika dan merupakan ruhnya matematika. Kemampuan yang ingin dicapai sesuai dengan tujuan pembelajaran matematika dalam kurikulum matematika kelas VIII (As'ari et al., 2017) adalah kemampuan: (1) memahami konsep matematika yang mencakup kompetensi dalam menjelaskan keterkaitan antar konsep maupun algortima secara luwes, akurat, tepat dalam pemecahan masalah. Termasuk dalam kompetensi ini adalah mampu menerapkan konsep matematika dalam melakukan operasi hitung, melakukan operasi aljabar, melakukan manipulasi ajlabar, dan keterampilan melakukan pengukuran; (2) menggunakan pola sebagai dugaan dalam penyelesaian masalah, dan mampu membuat generalisasi dari fenomena yang ada; (3) menggunakan penalaran (penalaran matematis) pada sifat, melakukan manipulasi matematika baik dalam menyederhanakan, maupun menganalisa komponen yang ada dalam pemecahan masalah dalam konteks matematika maupun di luar matematika (kehidupan nyata, ilmu dan teknologi) yang meliputi kemampuan memahami masalah, membangun model matematika, menyelesaikan model dan menafsirkan solusi yang diperoleh termasuk dalam menyelesaikan masalah dalam kehidupan nyata; (4) mengomunikasikan gagasan, penalaran serta mampu menyusun bukti matematika dengan menggunakan kalimat lengkap, simbol, tabel, diagram, atau media lain untuk memperjelas keadaan atau masalah; (5) memiliki sikap menghargai kegunaan matematika dalam kehidupan, yaitu memiliki rasa ingin tahu, perhatian, dan minat dalam mempelajari matematika, serta sikap ulet dan percaya diri dalam pemecahan masalah; (6) memiliki sikap dan perilaku yang sesuai dengan perilaku matematika dan pembelajarannya, seperti taat azas, konsisten, santun, demokrasi, cermat, teliti, dan terbuka; dan (7) menggunakan alat peraga sederhana maupun hasil teknologi untuk melakukan kegiatan-kegiatan matematika.

Kusumaningtyas et al. (2017) menyatakan bahwa tugas eksplorasi dapat berkontribusi pada perkembangan kemampuan pemecahan masalah siswa melalui analisis kasus-kasus. Suprihatin et al. (2018) menjelaskan bahwa materi matematika dan penalaran matematis adalah dua hal yang tidak dapat dipisahkan, yaitu materi matematika dipahami melalui penalaran, dan penalaran 
dipahami dan dilatihkan melalui belajar matematika. Dengan demikian matematika tidak hanya merupakan alat berpikir yang membantu siswa untuk menemukan pola, memecahkan masalah dan menarik kesimpulan, tetapi juga sebuah alat untuk mengomunikasikan pikiran tentang berbagai ide dengan jelas, tepat dan ringkas (Hodiyanto, 2017). Kecakapan atau kemampuan-kemampuan tersebut saling berkaitan antar satu sama lain, saling memperkuat dan saling membutuhkan. Sikapsikap yang terkandung dalam tujuan pembelajaran matematika poin (5) dan (6) termasuk ke dalam domain afektif yang disebut dengan disposisi matematik. Disposisi matematik adalah domain afektif yang memiliki peranan penting dalam pembelajaran matematika (Rahayu \& Kartono, 2014). Termasuk ke dalam disposisi matematik adalah kegigighan, ketekunan, dan keinginan yang kuat dalam mempelajari matematika (Munaji, 2019).

Terkait dengan disposisi matematik, faktor gender pada proses pembelajaran matematika dapat berpengaruh dalam menentukan prestasi belajar siswa. Gender merupakan atribut yang diasosiasikan kepada jenis kelamin seseorang, termasuk di dalamnya adalah peran, tingkah laku, preferensi yang menerangkan kelaki-lakian atau kewanitaan dalam konteks budaya tertentu (Nur \& Palobo, 2018). Menurut Setiadi et al. (2012), perempuan memiliki respon yang berbeda terhadap hal-hal yang dipelajari. Misalnya sikap rajin dan tekun dalam mempelajari matematika. Hal ini sejalan dengan pendapat (Colomeischi \& Colomeischi, 2015) yang mengatakan bahwa terdapat perbedaan sikap siswa laki-laki dan perempuan terhadap pembelajaran matematika. Siswa perempuan lebih baik dalam menyelesaikan masalah-masalah yang bersifat holistik sedangkan siswa laki-laki lebih baik dalam melakukan analisis permasalahan yang lebih spesifik. Lebih lanjut, (Benölken, 2015) berpendapat bahwa siswa laki-laki tidak berbakat dalam hal menunjukkan fungsional matematika dibandingkan siswa perempuan. Ini artinya bahwa siswa laki-laki yang memiliki keterbatasan dalam berpikir matematis lebih mampu menggunakan berbagai atribut matematika dalam pemecahan masalah dibandingkan siswa perempuan.

\section{Domain-Domain Penilaian TIMSS dan Standar Isi Kurkulum Matematika SMP}

Pengukuran kemampuan matematika oleh TIMSS 2015 di kelas VIII mengukur dua domain, yaitu domain konten dan domain kognitif. Dimensi konten berisi mata pelajaran sedangkan domain kognitif disajikan untuk melihat proses berpikir saat terkait dengan domain konten yaitu Bilangan, Aljabar, Geometri, serta Data dan Peluang. Sedangkan domain kognitif adalah pengetahuan (knowing), penerapan (applying) dan penalaran (reasoning). Distribusi persentase banyaknya instrumen soal domain konten dan kognitif disajikan Tabel 1.

Tabel 1. Distribusi instrumen soal

\begin{tabular}{clc}
\hline Domain & \multicolumn{1}{c}{ Kemampuan yang diukur } & Persentase \\
\hline Konten & Bilangan & $30 \%$ \\
& Aljabar & $30 \%$ \\
& Geometri & $20 \%$ \\
& Data dan Peluang & $20 \%$ \\
\multirow{5}{*}{ Kognitif } & Jumlah & $100 \%$ \\
& Mengetahui (knowing) & $35 \%$ \\
& Aplikasi (applying) & $40 \%$ \\
& Penalaran (reasoning) & $25 \%$ \\
& Jumlah & $100 \%$ \\
\hline
\end{tabular}

Penjelasan dari Tabel 1 di atas dapat dirinci sebagai berikut. Domain konten yang terdiri dari bilangan, aljabar, dan data dan peluang terdiri dari konten bilangan meliputi topik bilangan cacah, pecahan dan desimal, bilangan bulat, perbandingan, dan proporsi. Domain konten bilangan meliputi pemahaman bilangan, representasi dari bilangan, hubungan antara bilangan, dan sistem bilangan. Di kelas delapan, peserta didik harus telah mengembangkan sense bilangan dan kefasihan komputasi, memahami makna operasi dan bagaimana mereka berhubungan satu sama lain, dan dapat menggunakan bilangan dan operasi untuk memecahkan masalah. Domain aljabar termasuk mengenali pola, menggunakan simbol-simbol aljabar untuk merepresentasikan situasi matematika, 
dan mengembangkan kefasihan dalam mengekpresikan dan menyelesaikan persamaan linear. Peserta didik kelas harus mampu menganalisis sifat dan karakteristik dari berbagai macam bentuk geometri dua dimensi dan tiga dimensi, termasuk panjang sisi dan ukuran sudut, dan memberikan penjelasan berdasarkan pada hubungan geometris. Mereka harus mampu menerapkan teorema Pythagoras untuk memecahkan masalah. Fokusnya harus pada menggunakan sifat geometris. Peserta didik juga harus memiliki kompetensi dalam pengukuran geometris, dengan menggunakan alat ukur akurat, memperkirakan mana yang tepat, dan memilih menggunakan rumus untuk kelling, luas, dan volume. Konten geometri juga mencakup pemahaman representasi koordinat dan menggunakan keterampilan visualisasi spasial untuk melihat hubungan diantara representasi bentuk dua dan tiga dimensi. Peserta didik harus dapat menggunakan simetri dan menerapkan transformasi untuk menganalisis situasi matematika. Domain konten yang termasuk data dan peluang konten adalah mengetahui bagaimana mengatur data yang telah dikumpulkan oleh diri sendiri atau orang lain dan bagaimana menampilkan data dalam grafik dan diagram yang akan berguna dalam menjawab pertanyaan yang mendorong pengumpulan data. Ini domain konten termasuk isu-isu yang berkaitan dengan pemahaman kesalahan penafsiran data. Peserta didik harus mengembangkan keterampilan dalam mewakili data mereka menggunakan grafik batang, tabel, atau grafik garis. Mereka harus mampu mengenali dan membandingkan manfaat relatif dari berbagai jenis tampilan data.

Materi-materi yang hendak dinilai dalam TIMSS menggunakan istilah domain. Sedangkan pada kurikulum 2013 menggunakan istilah ruang lingkup materi. Ruang lingkup materi matematika yang diberikan kepada peserta didik tingkat SMP/MTs dalam Permendikbud No. 21 Tahun 2016 tentang Standar Isi Pendidikan Dasar dan Menengah mencakup: (1) bilangan rasional; (2) aljabar (pengenalan); (3) geometri (termasuk transformasi), (4) statistika dan peluang; dan (5) himpunan. Kompetensi yang harus dicapai peserta didik berdasarkan ruang lingkup materi tersebut yaitu: (a) menunjukkan sikap logis, kritis, analitis, cermat dan teliti, bertanggung jawab, responsif, dan tidak mudah menyerah dalam memecahkan masalah; (b) memiliki rasa ingin tahu, semangat belajar yang kontinu, rasa percaya diri, dan ketertarikan pada matematika; (c) memiliki rasa percaya pada daya dan kegunaan matematika, yang terbentuk melalui pengalaman belajar; (d) memiliki sikap terbuka, objektif dalam interaksi kelompok maupun aktivitas sehari-hari; (e) memiliki kemampuan mengkomunikasikan gagasan matematika dengan jelas; (f) mengidentifikasi pola dan menggunakannya untuk menduga perumuman/aturan umum dan memberikan prediksi; (g) memahami konsep bilangan rasional dilengkapi operasi dan urutan; (h) mengenal bentuk aljabar sederhana (linear, kuadrat); (i) memanfaatkan interpretasi geometri fungsi kuadrat dalam menyelesaikan persamaan; (j) memahami konsep himpunan dan operasinya serta fungsi dan menyajikan (diagram, tabel, grafik); (k) memahami bangun datar berdasarkan sifat-sifat atau fiturfitur (banyak sisi, keteraturan, ukuran), dan transformasi yang menghubungkannya; (I) memberi estimasi penyelesaian masalah dan membandingkannya dengan hasil perhitungan; $(\mathrm{m})$ menjelaskan dan memvisualisasikan pecahan yang ekuivalen; (n) membandingkan, memberi interpretasi berbagai metoda penyajian data; (o) memahami konsep peluang empirik; dan (p) menggunakan simbol dalam pemodelan, mengidentifikasi informasi, menggunakan strategi lain bila tidak berhasil.

Jika dianalisis, antara domian-domain pada TIMSS dengan domain konten yang berisi materi-materi matematika dan domain kognitif disajikan untuk melihat proses berpikir saat terkait dengan dimensi konten, maka secara umum ruang lingkup materi dan kompetensi yang akan dicapai dalam pembelajaran matematika dalam kurikulum matemtika SMP kelas VIII sudah sejalan dengan domain-domain penilaian pada TIMSS.

\section{METODE PENELITIAN}

Metode yang digunakan dalam penelitian ini adalah metode survei model cross-sectional survey dengan mengumpulkan data kemampuan matematika siswa SMP di kota Cirebon berdasarkan standar TIMSS dalam satu waktu. Teknik pengambilan sampel menggunakan teknik 
simple random sampling, dengan subyeknya adalah siswa kelas VIII SMP sebanyak 676 siswa dari sekolah negeri dan swasta. Pengumpulan data kemampuan matematika dilakukan dengan memberikan tes matematika model TIMSS yang telah diterjemahkan ke dalam bahasa Indonesia. Instrumen penelitian berupa tes matematika tersebut sebanyak 28 butir soal terdiri dari soal pilihan ganda dan isian (constructed response). Karena pengambilan data dalam masa pandemi covid-19, maka pemberian tes matematika dilakukan secara daring menggunakan aplikasi google form. Analisis data menggunakan pendekatan deskriptif kuantitatif berupa persentase siswa yang menjawab soal dengan benar dan metode penskoran items response theory (IRT) model dikotomi dengan 3 parameter untuk soal pilihan ganda dan model politomi dengan dua parameter untuk soal isian dengan bantuan software Bilog-MG Versi 3 (Retnawati, 2014). Hasil penskoran dengan IRT dikategorikan ke dalam empat kategori yaitu mahir (650), tinggi (550), menengah (475), dan rendah (400) (Setiadi et al., 2012). Data hasil penskoran menggunakan IRT digunakan untuk melakukan benchmarking skor TIMSS siswa secara keseluruhan dengan berpatokan kepada rata-rata skor TIMSS internasional yang mencapai 500 dan rata-rata skor TIMSS nasional yang mencapai 386 . Sedangkan data persentase siswa yang menjawab soal dengan benar digunakan untuk melakukan benchmarking kemampuan siswa yang menjawab soal TIMSS dengan benar berdasarkan level kemampuan pada penilaian TIMSS dengan berpatokan kepada rata-rata persentase siswa yang menjawab soal dengan benar tingkat internasional yang mencapai $75 \%$ pada level rendah, $46 \%$ pada level menengah, $17 \%$ pada level tinggi, 3\% pada level mahir dan pada tingkat nasional (Indonesia) yang mencapai 43\% pada level rendah, 15\% pada level menengah, 17\% pada level tinggi, 0\% pada level mahir (Setiadi et al., 2012). Persentase siswa yang menjawab soal dengan benar juga digunakan untuk mendeskripsikan kemampuan siswa dalam menjawab soal-soal TIMSS berdasarkan pada domain penilaian TIMSS dan berdasarkan perbedaan gender.

\section{HASIL DAN PEMBAHASAN}

TIMSS menampilkan empat tingkat pada skala sebagai standar internasional yaitu standar mahir, tinggi, menengah, dan rendah (Setiadi et al., 2012). Ini dilakukan untuk memberikan uraian bermakna mengenai arti kemampuan pada skala dalam kaitannya dengan pengetahuan dan kecakapan matematika para siswa. Indikator tingkat ketercapaian pada setiap standar adalah: (1) standar mahir: peserta didik dapat memberikan alasan berdasarkan informasi, menarik kesimpulan membuat generalisasi, dan memecahkan persamaan linear; (2) standar tinggi: peserta didik dapat menerapkan pemahaman dan pengetahuan mereka dalam berbagai situasi yang relatif kompleks; (3) standar menengah: peserta didik dapat menerapkan pengetahuan matematika dasar dalam berbagai situasi; dan (4) standar rendah: peserta didik memiliki pengetahuan tentang bilangan bulat dan desimal, operasi, dan grafik dasar.

Analisis data secara kuantitatif menggunakan metode penskoran items response theory (IRT) didapat skor rata-rata TIMSS siswa SMP di kota Cirebon mencapai 498. Pencapaian rata-rata skor TIMSS siswa di kota Cirebon, nasional, dan internasional disajikan dalam Tabel 2.

Tabel 2. Skor TIMSS siswa dalam benchmark nasional dan internasional

\begin{tabular}{clc}
\hline Partisipan & Skor & Kategori capaian \\
\hline Internasional & 500 & Menengah \\
Kota Cirebon & 498 & Menengah \\
Nasional (Indonesia) & 386 & Rendah \\
\hline
\end{tabular}

Berdasarkan Tabel 2 dapat dijelaskan bahwa skor TIMSS siswa di kota Cirebon yang mencapai 498 termasuk ke dalam kategori menengah lebih rendah 2 poin dengan skor TIMSS internasional namun masih sama dalam satu kategori menengah. Sedangkan bila dibandingkan dengan capaian skor TIMSS nasional sebesar 386 yang masuk dalam kategori rendah, skor TIMSS siswa SMP di kota Cirebon lebih unggul dibandingkan skor TIMSS siswa SMP secara nasional.

Secara keseluruhan, kemampuan matematika siswa SMP di kota Cirebon yang dapat menjawab soal dengan benar mencapai $50 \%$ dengan standar deviasinya $8 \%$. Untuk ukuran sampel 
sebanyak 676 responden dan taraf signifikansi sebesar 95\%, maka dengan menggunakan confidence function pada excel didapat margin of error sebesar 0,6. Dengan formula interval kepercayaan (Singpurwalla, 2015), yaitu:

$$
\text { Interval Kepercayaan = estimasi } \pm \text { margin of error }
$$

Maka didapat nilai interval persentase siswa yang menjawab soal dengan benar antara $50,4 \%-49,6 \%$. Ini artinya jika sampel diuji beberapa kali dengan metode yang sama dengan taraf signifikansi 95\%, kita percaya bahwa nilai kemampuan matematika siswa SMP di kota Cirebon (sebagai populasi) berkisar antara $49,4 \%$ sampai dengan $50,6 \%$.

\section{Kemampuan Matematika Siswa dalam Level Rendah (Low)}

Pada level rendah dalam domain bilangan siswa diharapkan mampu melakukan operasi hitung berbagai macam bilangan (bilangan bulat, pecahan, pangkat bulat positif) dengan prosedur rutin, dan dalam domain data dan peluang siswa diharapkan mampu membaca data dengan tepat sesuai informasi yang terdapat pada tabel, menuliskan informasi ke dalam grafik dasar dengan benar.

Rata-rata persentase siswa yang menjawab soal dengan benar pada level rendah mencapai $80,5 \%$, lebih tinggi dari rata-rata skor internasional yang mencapai $75 \%$ dan skor nasional yang hanya 43\% pada TIMSS 2011.

\begin{aligned} \multicolumn{3}{c}{ Berapakah nilai dari $3^{3}$ ? } \\ $\begin{aligned} \text { a. } 6 & \text { c. } 9 \\ \text { b. } 27 & \text { d. } 33\end{aligned}\end{aligned}$

\section{Gambar 1. Contoh soal materi terkait bilangan}

Siswa yang menjawab dengan benar pada Gambar 1 sebesar $52 \%$. Konsepnya ialah bahwa untuk setiap bilangan a $(a \neq 0)$ dengan pangkat $n$ (bilangan bulat positif) adalah perkalian berulang dari a sebanyak $n$ kali. Sebagian kecil siswa masih bingung mengenai konsep bilangan pangkat bulat positif. Sekitar 1,2 \% mungkin menganggap bahwa $3^{3}=3+3=6$. Sekitar $11,1 \%$ siswa mungkin menganggap bahwa $3^{3}=3 \times 3=9$, dan sekitar $1,3 \%$ siswa kemungkinan menganggap bahwa $3^{3}=33$ ini sangat tidak masuk akal. Dari penyelesaian siswa pada Gambar 1 ini kita juga bisa mengetahui bahwa sense of number siswa masih lemah. Beberapa siswa masih belum bisa membaca bilangan pangkat bulat positif dengan baik. Contoh soal materi terkait data dan peluang ditampilkan pada Gambar 2.

Sebanyak 100 siswa di sebuah sekolah diukur tinggi badannya dalam satuan centi meter $(\mathrm{cm})$. Tabel berikut menunjukkan hasil pengukuran tinggi badan siswa tersebut.

\begin{tabular}{|l|l|l|l|l|}
\hline Tinggi Badan (cm) & 145 & 150 & 155 & 160 \\
\hline Jumlah Siswa & 16 & 40 & 25 & 19 \\
\hline
\end{tabular}

Lengkapilah grafik di bawah ini dengan informasi yang sama dengan tabel.

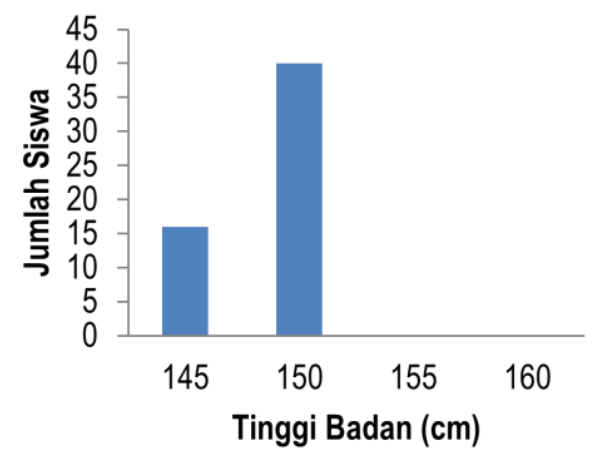

Gambar 2. Contoh soal materi terkait data dan peluang 
Siswa yang menjawab dengan benar pada soal Gambar 2 sebanyak $78 \%$. Soal ini termasuk dalam domain konten data dan peluang dengan domain kognitif yang diuji adalah knowing. Tujuan dari soal ini adalah untuk melihat kemampuan siswa dalam membaca grafik. Dengan demikian masih ada $22 \%$ siswa yang belum bisa membaca grafik dengan tepat.

\section{Kemampuan Matematika Siswa dalam Level Menengah (Intermediate)}

Pada level menengah dalam dimensi aljabar siswa diharapkan mampu melakukan operasi hitung, menyederhanakan, dan melakukan evaluasi pada bentuk ekspresi aljabar sederhana. Dalam dimensi geometri siswa diharapkan mampu memahami representasi koordinat dan menggunakan keterampilan visualisasi spasial untuk melihat hubungan diantara representasi bentuk dua dan tiga dimensi. Siswa diharapkan dapat menggunakan simetri dan menerapkan transformasi untuk menganalisis situasi matematika.

Rata-rata persentase siswa yang menjawab soal dengan benar di kota Cirebon pada level menengah mencapai $62 \%$, lebih tinggi di atas persentase rata-rata internasional yang mencapai $46 \%$ dan rata-rata nasional yang mencapai $15 \%$ pada TIMSS 2011. Selanjutnya soal pada materi yang berhubungan dengan aljabar disajikan pada Gambar 3 .

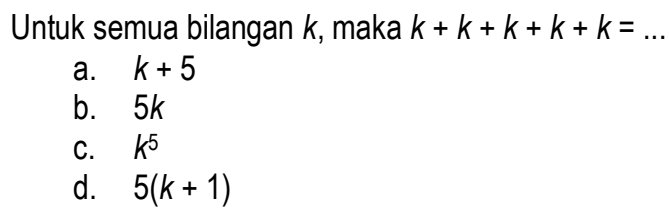

Gambar 3. Contoh soal materi terkait aljabar

Jika dilihat dari jawaban siswa, sebanyak $52,3 \%$ memilih jawaban b. $5 k$ yang merupakan jawaban benar dari soal tersebut. Sebanyak $8,4 \%$ siswa menjawab pilihan jawaban a. $k+5$. Sebanyak $32,3 \%$ siswa menjawab c. $k^{5}$, dan $7 \%$ siswa menjawab pilihan jawaban d. $5(k+1)$. Soal ini mengungkap pemahaman siswa dalam melakukan operasi dasar bentuk aljabar. Kekeliruan siswa tampak pada jawaban salah yang menganggap bahwa $k+k+k+k+k$ adalah $k+5$ atau $k^{5}$.

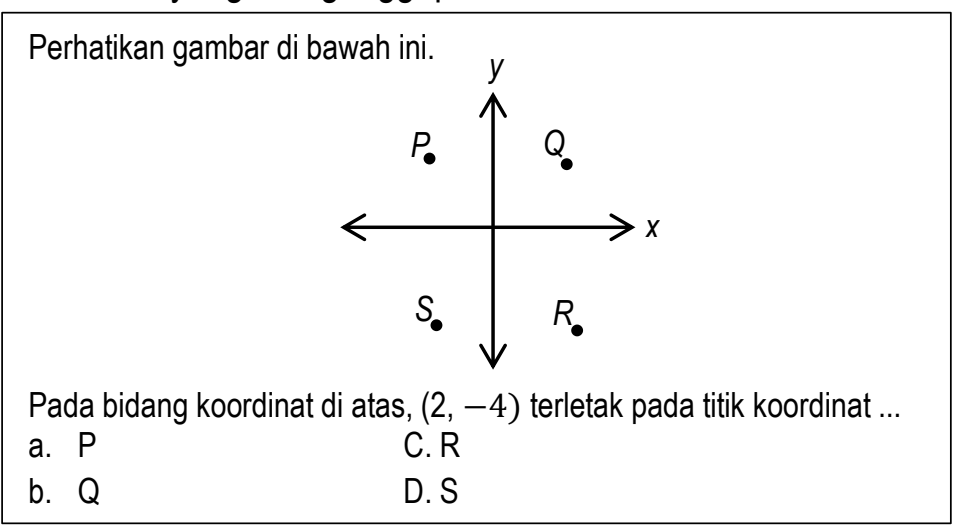

Gambar 4. Contoh soal materi geometri

Contoh soal pada Gambar 4 termasuk dalam domain konten geometri dan domain kognitif knowing. Dalam soal tersebut menguji siswa dalam pemahaman representasi koordinat dan menggunakan keterampilan visualisasi spasial untuk melihat hubungan diantara representasi bentuk dua dimensi. Sebanyak $79 \%$ atau sebagian besar siswa dapat menjawab soal dengan benar, sedangkan sisanya hanya sekitar $21 \%$ menjawab soal dengan salah.

3. Kemampuan Matematika Siswa dalam Level Tinggi (High)

Kemampuan siswa pada level tinggi ditunjukkan dengan kemampuan siswa dalam menyampaikan alasan berdasarkan informasi, menarik kesimpulan, membuat generalisasi, dan menyelesaikan persamaan linear. Dalam dimensi bilangan peserta didik dapat memecahkan 
berbagai pecahan, proporsi, dan masalah persen yang membenarkan kesimpulan mereka. Dalam dimensi aljabar siswa dapat mengekspresikan generalisasi aljabar dari suatu model. Mereka dapat menyelesaikan berbagai masalah yang melibatkan persamaan, rumus, dan fungsi. Selanjutnya dalam dimensi geometri dan pengukuran peserta didik dapat memberikan alasan dengan bangun geometri untuk memecahkan masalah, dan terkait dengan data dan peluang peserta didik dapat memberikan alasan dengan data dari beberapa sumber atau representasi yang tidak umum untuk memecahkan masalah multi-langkah.

Rata-rata persentase siswa yang menjawab soal dengan benar di kota Cirebon pada level tinggi mencapai $57,4 \%$ lebih tinggi dari rata-rata persentase internasional yang mencapai $17 \%$ dan nasional 2\% pada TIMSS 2011 (Setiadi et al., 2012).

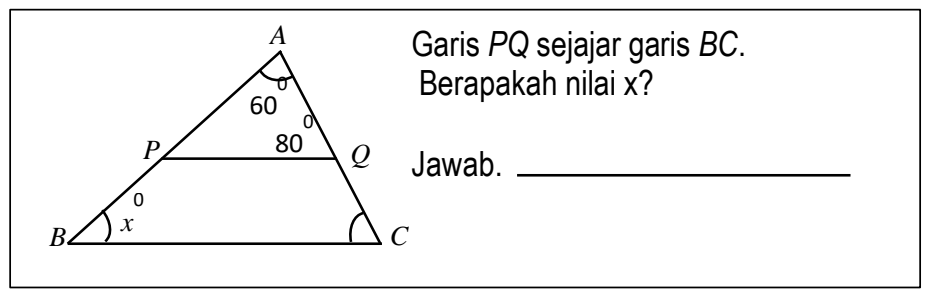

Gambar 5. Contoh soal materi terkait geometri

Soal ini termasuk ke dalam domain konten geometri dan domain kognitif applying. Pada soal tersebut siswa diminta menghitung besarnya sudut yang belum diketahui yaitu $x^{0}$ jika beberapa sudut diketahui. Untuk menjawab soal tersebut siswa perlu memahami bahwa jumlah sudut dalam segitiga adalah $180^{\circ}$, dan besar sudut dalam sepihak adalah sama. Sudut $P+A+Q=180^{\circ}$. Sehingga $P+60^{\circ}+80^{\circ}=180^{\circ}$ dan $P=180^{\circ}-\left(60^{\circ}+80^{\circ}\right)=40^{\circ}$. Sudut $x^{0}=P$, jadi $x=40$. Hasil penelitian ini menunjukkan hanya $37 \%$ siswa yang menjawab dengan benar dan sebagian besarnya $63 \%$ menjawab salah. Ada banyak kemungkinan penyebabnya sehingga siswa belum berhasil menjawab dengan benar, antara lain siswa kurang memahami pengetahuan terkait sudut dalam segitiga, serta hubungan antar sudut. Penyebab lain adalah siswa kurang terbiasa melakukan penalaran.

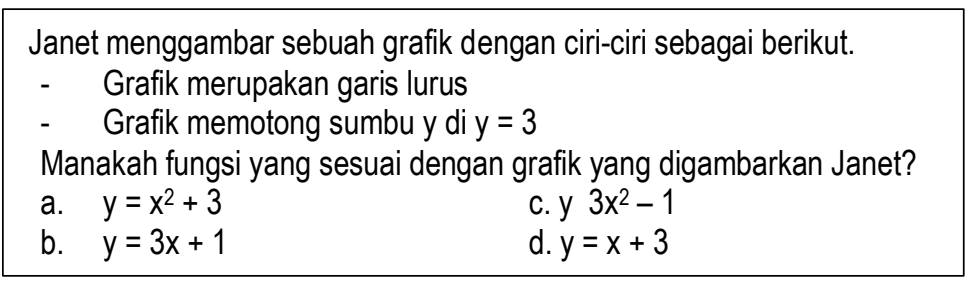

Gambar 6. Contoh soal materi terkait aljabar

Soal tersebut termasuk ke dalam domain konten aljabar dan domain kognitif applying. Dalam soal tersebut siswa diuji untuk dapat menggunakan simbol-simbol aljabar untuk merepresentasikan situasi matematika, dan mengembangkan kefasihan dalam mengekpresikan dan menyelesaikan persamaan linear dengan mengetahui sifat-sifat grafik fungsi linear. Sebanyak $46 \%$ siswa yang dapat menjawab soal pada Gambar 6 dan sebagian besarnya, yaitu 54\% siswa menjawabnya dengan salah.

\section{Kemampuan Matematika Siswa dalam Level Mahir (Advance)}

Pada level mahir kemampuan yang ingin dicapai adalah siswa dapat memberikan alasan terkait berbagai jenis bilangan dalam situasi rutin dan non-rutin dan membenarkan kesimpulan mereka. Siswa mampu mengekspresikan generalisasi bentuk aljabar, dan menyelesaikan berbagai masalah yang melibatkan persamaan, rumus, dan fungsi. Mereka dapat memberikan alasan dengan bentuk geometri untuk memecahkan masalah dan dengan data dari beberapa sumber untuk memecahkan masalah multi-langkah. 
Rata-rata persentase siswa SMP di kota Cirebon yang menjawab soal dengan benar pada level mahir mencapai 39,2\% lebih tinggi dari rata-rata persentase internasional yang mencapai persentase sebesar 3\% dan nasional 0\% pada TIMSS 2011 (Setiadi et al., 2012).

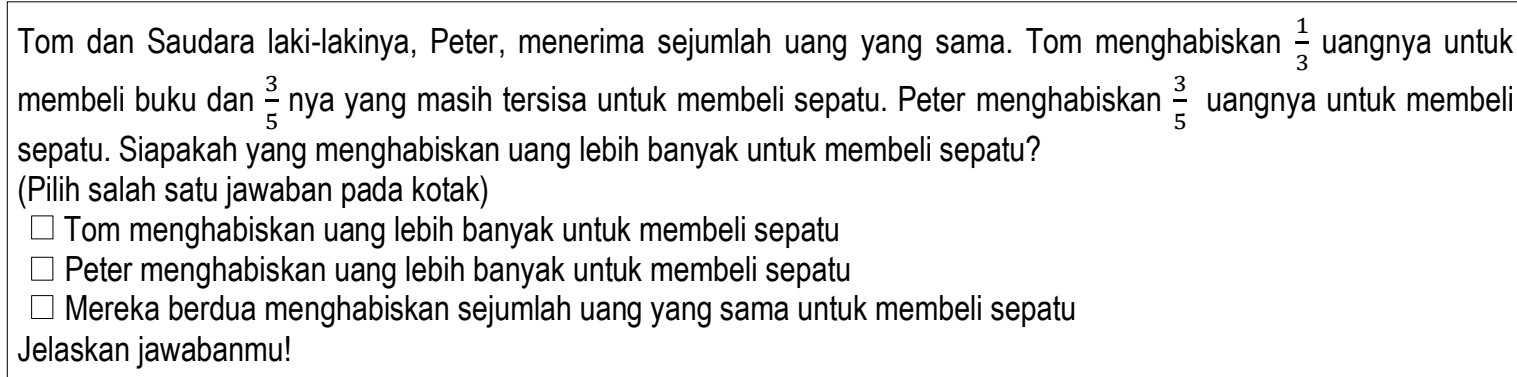

Gambar 7. Contoh soal materi terkait bilangan

Soal pada Gambar 7 termasuk ke dalam domain konten bilangan dan domain kognitif reasoning. Soal tersebut menguji kemampuan siswa dalam melakukan penalaran mengenai pecahan merupakan bagian dari keseluruhan dalam masalah-masalah nyata sehari-hari dan menjelaskan alasan dari sebuah jawaban. Hanya $23,4 \%$ siswa yang menjawab soal dengan benar, dan sisanya sebagian besar menjawab salah. Diantara jawaban siswa yang benar: "Peter menghabiskan uang lebih banyak untuk membeli sepatu, karena $3 / 5$ dari $2 / 3$ adalah $2 / 5$, sedangkan $3 / 5$ dari 1 adalah 3/5. 3/5 lebih besar dari 2/5, jadi Peter menghabiskan uang lebih banyak". Diantara jawaban siswa yang salah: "Tom menghabiskan uang lebih banyak untuk membeli sepatu, karena Tom belanja uangnya $1 / 3$ dan $3 / 5$, sedangkan Peter hanya belanja $3 / 5$ saja". Dari jawaban salah terlihat siswa kurang memahami bahwa pecahan merupakan bagian dari keseluruhan. Kemungkinan kekeliruan yang lain adalah siswa tidak bisa melakukan operasi pengurangan pecahan dan tidak bisa membandingkan mana pecahan yang lebih besar dan mana yang lebih kecil. Walaupun soal tersebut masuk dalam domain konten namun untuk menjawabnya perlu memiliki kemampuan penalaran yang tinggi dan menguasai konsep-konsep dasar operasi pecahan.

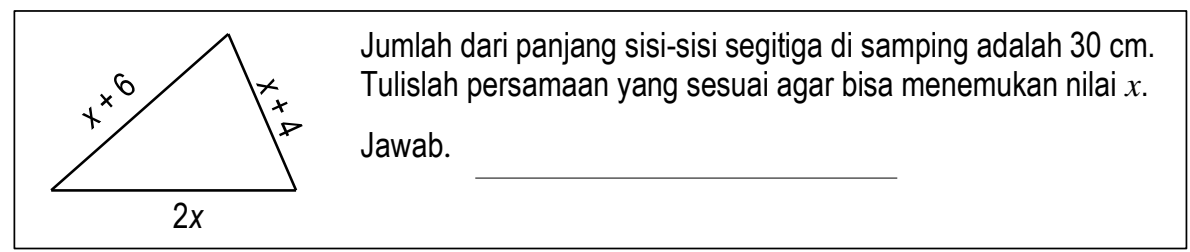

Gambar 8. Contoh soal materi aljabar

Soal pada Gambar 8 termasuk dalam domain konten aljabar dan domain kognitif reasoning. Soal tersebut menguji siswa untuk bisa membuat model matematika berupa persamaan dengan tepat sesuai dengan informasi yang tersedia berupa panjang sisi-sisi segitiga dalam bentuk variabel. Konsep dasar yang harus dimiliki adalah penjumlahan bentuk aljabar dan sebelumnya harus telah memahami terlebih dahulu pengetahuan tentang suku, koefisien, konstanta, dan suku-suku sejenis. Dalam penjumlahan bentuk aljabar, suku-suku yang dapat dijumlahkan adalah suku yang sejenis yaitu suku yang memiliki varaiabel dan pangkat variable yang sama. Jawaban siswa pada soal Gambar 8 sangat tidak memuaskan, tidak ada siswa satupun yang dapat menjawab soal tersebut dengan benar. hal ini menunjukkan bahwa kemampuan siswa dalam membuat model matemtika masih sangat lemah.

\section{Kemampuan Matematika Siswa dalam Domain TIMSS}

Pencapaian persentase jawaban siswa yang mampu menjawab soal dengan benar jika dilihat dari segi domain konten yang terdiri dari konten bilangan, aljabar, geometri, data dan peluang, serta domain koginitif yang terdiri atas knowing, applying, dan reasoning disajikan pada Tabel 3. 
Tabel 3. Persentase jawaban benar pada domain penilaian TIMSS

\begin{tabular}{llc}
\hline Domain & Kemampuan yang diukur & Persentase \\
\hline Konten & Bilangan & $49 \%$ \\
& Aljabar & $41 \%$ \\
& Geometri & $55 \%$ \\
\multirow{5}{*}{ Kognitif } & Data dan Peluang & $61 \%$ \\
& Knowing & $67 \%$ \\
& Applying & $37 \%$ \\
& Reasoning & $47 \%$ \\
\hline
\end{tabular}

Dari Tabel 3 dapat dijelaskan bahwa sebanyak 49\% siswa menjawab soal dengan benar pada domian bilangan, $41 \%$ siswa menjawab soal dengan benar pada domian aljabar, $55 \%$ siswa menjawab soal dengan benar pada domain geometri, dan $61 \%$ siswa menjawab soal dengan benar pada domain data dan peluang. Sedangkan pada domain kognitif, $67 \%$ siswa menjawab soal dengan benar pada domain knowing, 37\% siswa menjawab soal dengan benar pada domain applying, dan $47 \%$ siswa menjawab soal dengan benar pada domain reasoning. Dari data pada Tabel 3 dapat pula dijelaskan bahwa kemampuan matematika yang paling tinggi pada domain konten terdapat pada konten data dan pelung persentasenya mencapai di atas $60 \%$, sedangkan pada konten bilangan, aljabar, dan geometri persentasenya masih di bawah $60 \%$. Siswa yang mampu memahami serta mengaitkan antar konsep matematika maka pemahaman konsep yang dimiliki siswa akan lebih dalam serta bertahan lama (Nurhayati et al, 2020). Apabila dilihat berdasarkan domain kognitif, kemampuan matematika siswa paling tinggi terdapat pada domain kognitif knowing yang persentasenya mencapai di atas 60\%, sedangkan pada domain kognitif applying dan reasoning pencapaian masih rendah yaitu di bawah $50 \%$.

\section{Kemampuan Matematika Siswa Berdasarkan Gender}

Berdasarkan keseluruhan sampel yang diuji sebanyak 676 siswa, jumlah siswa laki-laki adalah sebanyak 267 siswa atau 39,5\% dari keseluruhan jumlah sampel, sedangkan siswa perempuan adalah sebanyak 400 siswa atau $60,5 \%$ dari dari keseluruhan jumlah sampel. Pencapaian persentase jawaban benar secara umum berdasarkan gender disajikan pada Tabel 4 .

Tabel 4. Persentase jawaban benar secara umum berdasarkan gender

\begin{tabular}{cc}
\hline Gender & Persentase \\
\hline Laki-Laki & $48 \%$ \\
Perempuan & $56 \%$ \\
\hline
\end{tabular}

Dari Tabel 4 dapat dijelaskan bahwa siswa laki-laki yang mampu menjawab soal dengan benar mencapai $48 \%$. Dengan demikian, $52 \%$ dari siswa laki-laki tidak dapat menjawab soal dengan benar. Dapat dikatakan bahwa jumlah siswa laki-laki yang menjawab soal dengan benar lebih kecil dari siswa laki-laki yang tidak dapat menjawab soal dengan benar. Sedangkan siswa perempuan yang mampu menjawab soal dengan benar mencapai 56\%. Dengan demikian, 44\% dari siswa perempuan tidak dapat menjawab soal dengan benar. Dapat dikatakan bahwa siswa perempuan yang menjawab soal dengan benar lebih banyak dari siswa perempuan yang tidak dapat menjawab soal dengan benar. Namun, persentase siswa perempuan yang menjawab soal dengan benar masih rendah, yaitu di bawah $60 \%$.

Bila ditinjau dari segi perbedaan gender berdasarkan level pada kemampuan penilaian TIMSS, persentase capaian tiap level dari level rendah, menengah, tinggi, dan mahir untuk siswa laki-laki dan perempuan disajikan pada Tabel 5.

Tabel 5. Persentase jawaban benar dalam level kemampuan TIMSS berdasarkan gender

\begin{tabular}{ccc}
\hline Level & Laki-Laki & Perempuan \\
\hline Rendah & $77 \%$ & $83 \%$ \\
Menengah & $58 \%$ & $65 \%$ \\
Tinggi & $53 \%$ & $60 \%$ \\
Mahir & $36 \%$ & $41 \%$ \\
\hline
\end{tabular}


Dari Tabel 5 dapat dijelaskan bahwa persentase capaian tiap level dari level rendah, menengah, tinggi, dan mahir untuk siswa laki-laki berturut-turut yaitu $77 \%, 58 \%, 53 \%$, dan $36 \%$. Sedangkan persentase capaian tiap level dari level rendah, menengah, tinggi, dan mahir untuk siswa perempuan berturut-turut $83 \%, 65 \%, 60 \%$, dan $41 \%$. Dari Tabel 3 bisa dijelaskan bahwa pencapaian persentase jawaban benar siswa perempuan lebih tinggi dibandingkan pencapaian persentase jawaban benar siswa laki-laki pada setiap level penilian TIMSS, baik itu level rendah, menengah, tinggi, maupun mahir.

Bila ditinjau berdasarkan domain konten penilaian TIMSS, secara terperinci pencapaian persentasi siswa yang dapat menjawab soal dengan benar pada konten bilangan, aljabar, geometri, data dan peluang disajikan pada Tabel 6 .

Tabel 6. Persentase jawaban benar pada domain penilaian TIMSS berdasarkan gender

\begin{tabular}{llcc}
\hline Domain & Kemampuan yang diukur & Laki-Laki & Perempuan \\
\hline Konten & Bilangan & $45 \%$ & $52 \%$ \\
& Aljabar & $38 \%$ & $43 \%$ \\
& Geometri & $51 \%$ & $57 \%$ \\
\multirow{5}{*}{ Kognitif } & Data dan Peluang & $58 \%$ & $63 \%$ \\
& Knowing & $63 \%$ & $70 \%$ \\
& Applying & $34 \%$ & $38 \%$ \\
& Reasoning & $43 \%$ & $49 \%$ \\
\hline
\end{tabular}

Dari Tabel 6 dapat dijelaskan bahwa pada konten bilangan siswa laki-laki yang mampu menjawab soal dengan benar mencapai $45 \%$, pada konten aljabar mencapai $38 \%$, pada konten geometri mencapai $51 \%$, dan pada konten data dan peluang mencapai $58 \%$. Sedangkan siswa perempuan pada konten bilangan mampu menjawab soal dengan benar mencapai $52 \%$, pada konten aljabar mencapai $43 \%$, pada konten geometri mencapai $57 \%$, dan pada konten data dan peluang mencapai $63 \%$.

Sedangkan apabila ditinjau berdasarkan domain kognitif, pada domain knowing siswa lakilaki yang mampu menjawab soal dengan benar mencapai $63 \%$, pada domain applying mencapai $34 \%$, dan pada domain reasoning mencapai $43 \%$. Sedangkan siswa perempuan pada domain knowing mampu menjawab soal dengan benar mencapai $70 \%$, pada domain applying mencapai $38 \%$, dan pada domain reasoning mencapai $49 \%$.

Dengan demikian dapat dikatakan bahwa kemampuan matematika siswa perempuan SMP di kota Cirebon berdasarkan standar TIMSS lebih baik dibandingkan siswa laki-laki. Hal ini sejalan dengan laporan penelitian TIMSS 2011 oleh Setiadi et al. (2012) yang menyatakan bahwa siswa perempuan di Indonesia lebih unggul dibandingkan siswa laki-laki.

\section{KESIMPULAN}

Berdasarkan hasil analisis data dan hasil pembahasan, maka hasil penelitian ini dapat disimpulkan sebagai berikut: rata-rata kemampuan matematika siswa SMP di kota Cirebon berdasarkan standar TIMSS mencapai 498 dalam kategori menengah lebih baik dari rata-rata kemampuan matematika siswa secara nasional yang hanya mencapai 386 dalam kategori rendah. Jika dibandingkan rata-rata skor TIMSS internasional yang mencapai 500, rata-rata skor TIMSS siswa Indonesia 2 poin lebih rendah, namun masih sama dalam ketegori menengah. Kemampuan matematika siswa SMP di kota Cirebon masih perlu ditingkatkan lagi karena bila ditinjau dari kemampuan matematika siswa pada level tinggi dan mahir atau pada domain kognitif applying dan reasoning siswa yang menjawab soal dengan benar masih di bawah $50 \%$. Persentase siswa yang menjawab dengan benar di atas $60 \%$ hanya pada domain knowing. Kelemahan siswa terlihat dari jawaban siswa yang kurang mampu dalam menjawab soal-soal yang memerlukan penalaran yang terkait dengan bilangan, operasi hitung pecahan termasuk membadingkan pecahan dalam menyelesaikan masalah sehari-hari, membuat pemodelan matematika dalam bentuk aljabar, menemukan pola, dan analisis hubungan representasi dalam geometri. Adapun dari segi perbedaan gender, siswa perempuan di kota Cirebon lebih unggul dibandingkan dengan siswa lakilaki. 


\section{REKOMENDASI}

Perlu adanya penelitian lebih lanjut untuk mengetahui faktor-faktor apa saja yang bisa meningkatkan kemampuan matematika siswa SMP di kota Cirebon berdasarkan standar TIMSS, terutama penelitian dengan inovasi berbasis teknologi guna mendukung adaptasi kebiasaan baru (AKB) atau new normal di masa pandemi covid-19.

\section{UCAPAN TERIMA KASIH}

Dalam kesempatan ini penulis mengucapkan terima kasih sebanyak-banyaknya kepada pihak-pihak yang telah mendukung berjalannya penelitian ini, yaitu: (1) DRPM Kementrian Riset dan Teknologi/Badan Riset dan Inovasi Nasional yang telah memberikan pendanaan; (2) Kepala Dinas Pendidikan Kota Cirebon yang telah memberikan izin dan rekomendasi; (3) Prof. Dr. H. M. Guntoro, M.Si, M.M., yang telah memberikan izin dan dukungan yang luar biasa; (4) Para kepala sekolah dan guru yang tergabung dalam Musyawarah Guru Mata Pelajaran (MGMP) Matematika yang telah memberikan izin dan kerjasamanya yang sangat baik; serta (5) Siswa-siswi yang telah mengikuti survei dan senantiasa bersemangat untuk terus belajar dan belajar matematika.

\section{DAFTAR PUSTAKA}

Ani, E. U., \& Rahayu, P. (2018). Profil kemampuan pemecahan masalah matematika siswa berbentuk soal cerita materi bangun ruang. Jurnal Riset Pendidikan dan Inovasi Pembelajaran Matematika (JRPIPM). https://doi.org/10.26740/jrpipm.v1n1.p40-49.

As'ari, A. R., Tohir, M., Valentino, E., Imron, Z., \& Taufiq, I. (2017). Buku guru matematika SMP/MTs kelas viii. Cetakan Ke-2. Kementrian Pendidikan dan Kebudayaan.

Benölken, R. (2015). Gender-and giftedness-specific differences in mathematical self-concepts, attributions and interests. Procedia-Social and Behavioral Sciences. https://doi.org/10.1016/j.sbspro.2015.01.690.

Colomeischi, A. A., \& Colomeischi, T. (2015). The students 'emotional life and their attitude toward mathematics learning. Procedia-Social and Behavioral Sciences. https://doi.org/10.1016/j.sbspro.2015.02.192.

Hari, S. (2012). Kemampuan matematika siswa SMP Indonesia dalam benchmark internasional TIMSS 2011 (Rahmawati (ed.)).

Hodiyanto, H. (2017). Kemampuan komunikasi matematis dalam pembelajaran matematika. AdMathEdu: Jurnal IImiah Pendidikan Matematika, IImu Matematika dan Matematika Terapan. https://doi.org/10.12928/admathedu.v7i1.7397.

Kusumaningtyas, S. I., Juniati, D., \& Lukito, A. (2017). Pemecahan masalah generalisasi pola siswa kelas vii smp ditinjuau dari gaya kognitif field independent dan field dependent. Kreano, Jurnal Matematika Kreatif-Inovatif. https://doi.org/10.15294/kreano.v8i1.6994.

Munaji. (2019). Penerapan model pembelajaran kooperatif tipe jigsaw untuk meningkatkan disposisi matematis siswa. AKSIOMA: Jurnal Matematika dan Pendidikan Matematika, 10(2). https://doi.org/10.26877/AKS.V1012.3960. 
Musyafa. (2020). Pendekatan contextual teaching and learning (ctl) untuk meningkatkan pemahaman matematik siswa pada materi aritmatika sosial. Teorema: Teori dan Riset Matematika, 5(1), 69-76.

Nur, A. S., \& Palobo, M. (2018). Profil kemampuan pemecahan masalah matematika siswa ditinjau dari perbedaan gaya kognitif dan gender. Kreano. https://doi.org/http://dx.doi.org/10.15294/kreano.v9i2.15067.

Nurhayati, Y., Zakiah, N. E., \& Amam, A. (2020). Integrasi contextual teaching learning (ctl) dengan geogebra: dapatkah meningkatkan kemampuan koneksi matematis siswa?. Teorema: Teori dan Riset Matematika, 5(1), 27-34.

OECD. (2019). PISA 2018 results (volume I). OECD Publishing. https://doi.org/10.1787/5f07c754-en.

Rahayu, R., \& Kartono. (2014). The effect of mathematical disposition toward problem solving ability based on ideal problem solver. International Journal of Science and Research.

Retnawati, H. (2014). Teori respons butir dan penerapannya untuk peneliti, praktisi pengukuran dan pengujian, mahasiswa pascasarjana. Parama Publishing.

Setiadi, H., Mahdiansyah, Rosmawati, R., Fahmi, \& Afiani, E. (2012). Kemampuan matematika siswa smp indonesia menurut benchmark internasional TIMSS 2011. Pusat Penilaian Pendidikan Badan Penelitain dan Pengembangan Kementrian Pendidiikan dan Kebudayaan.

Shintawati, E., \& Jupri, A. (2018). Analysis of students' incorrect answers at triangle materials in the fifth-grade of primary school. Journal of Physics: Conference Series. https://doi.org/10.1088/1742-6596/1013/1/012145

Singpurwalla, D. (2015). A hand book of statistics an overview of statistical methods. Book Boon. bookboon.com

Suprihatin, T. R., Maya, R., Senjayawati, E., \& Siliwangi, I. (2018). Analisis kemampuan penalaran matematis siswa smp pada materi segitiga dan segiempat. Jurnal Kajian Pembelajaran Matematika, 2(1). http://journal2.um.ac.id/index.php/jkpm

Utami, R. E., Ekawati, C., \& Handayanto, A. (2020). Profil kemampuan berpikir aljabar dalam memecahkan masalah matematika ditinjau dari gaya kognitif reflektif siswa smp. JIPMat. https://doi.org/10.26877/jipmat.v5i1.5502

Wardhani, S., \& Rumiati. (2011). Instrumen penilaian hasil belajar matematika SMP: Belajar dari TIMSS dan PISA. Kementrian Pendidikan Nasional Badan Pengembangan Sumber Daya Manusia Pendidikan dan Penjamin Mutu Pendidikan Pusat Pengembangan dan Pemberdayaan Pendidikan dan Tenaga Kependidikan (PPPPTK) Matematika.

Yunia, N., \& Zanthy, L. S. (2020). Kesalahan siswa smp dalam menyelesaikan soal cerita pada materi aritmatika sosial. Teorema: Teori dan Riset Matematika, 5(1), 105-116. 